\author{
山崎 光 悦*1, 深 作 亮 太*2 \\ 北山哲 士*1, 古栃 真*3

\section{Development of Cell Structure for Impact Energy Absorption with Film Ruptures}

\author{
Koetsu YAMAZAKI*4, Ryota FUKASAKU, \\ Satoshi KITAYAMA and Makoto FURUTOCHI
}

${ }^{*}$ Department of Human \& Mechanical Systems Engineering, Kanazawa University, Kakuma-machi, Kanazawa-shi, Ishikawa, 920-1192 Japan

\begin{abstract}
The effect of honeycomb cell structure with thin film subjected to an axial impact force is studied by FEM, and a quatitative comparison between numerical estimates and experimental results are made and discussed. Numerical simulation shows that for enhancing the energy absorption capability, causing plastic crush of honeycomb cell and penetration of aluminum films simultaneously can be preferable than thickening the cell wall or reducing the size of honeycomb cell. Moreover, reducing the impact force (peak load) technique for honeycomb cell structure is developed and applied to the axial crushing of honeycomb cell structure with thin film ruptures. Based on the numerical results, the experiments on the collapse of honeycomb cell structure with thin film have been carried out under dynamic condition, and it is found that the numerical results agreed well for impact energy absorbed amount and crushing mode.
\end{abstract}

Key Words: Impact Strength, Finite Element Method, Buckling, Honeycomb Cell, Energy Absorption, Film Rupture

\section{1. 緒 論}

ハニカムセル構造材は, 衝撃エネルギー吸収構造材 の中でも特に軽量, かつ高剛性・高強度の構造材であ り, ジェット旅客機や人工衛星をはじめとする航空宇 宙産業分野での使用が著しい(1)(2). 元来, 八ニカムセ ルはサンドイッチ構造用のコア材として開発されたも のであり，ハニカムセルの両面に接着剤などで表面板 を張ったハニカムサンドイッチパネルは, 構造材とし てさまざまな分野で使用されている，例えば，現在の 航空機の機体はアルミニウム製またはペーパ樹脂製ハ ニカムセル, もしくは硬いポリマフォームの両面に GFRP や CFRP の薄板を張り合わせて, 比岡性と比 強度を著しく高めたサンドイッチパネルで作られてい る. 同様の技法は軽量化が至上命題となる宇宙飛翔 体, スキー板, レーシングヨット, 移動式建物などの 分野にも広がっている(3). また, 最近では耐熱強度の 要求に応じた溶接接合ハニカムパネルも開発されてい

* 原稿受付 2006 年 3 月 22 日.

*1 正員, 金沢大学大学院自然科学研究科(ङ920-1192 金沢市 角間町).

*2 学生員, 金沢大学大学院自然科学研究科.

*3 立山アルミニウム工業 (株) (昰933-8602 高岡市早川 550).

E-mail : yamazaki@t.kanazawa-u.ac.jp
$ろ^{(4)(5)}$.

ハニカムセルやパネルはセル軸方向に圧縮すると, 初期圧潰荷重と呼ばれる最大ピーク荷重を生じた後, その約 $1 / 2$ の荷重を支えて完全圧潰するまで, 連続的 に折り畳まれるよう圧潰していくことから, 衝撃エネ ルギーを吸収する緩衝材としても注目されている。こ れまでに, 円筒や角筒の衝撃圧潰現象解明に関する研 究が数多く行われており, 自動車車体の衝撃エネルギ 一吸収部材などに多く応用されている(6)(7). 一方で, 八ニカムセル構造材に関しては, これまで主として曲 げ試験やせん断試験に関する研究が多く報告されてき た(4)(8). しかし, ハニカムセル構造材の衝撃エネルギ 一吸収材料としての適用分野が拡大するに伴い, 単段 あるいは多段に積層したハニカムパネルに飛翔体を衝 突させる衝撃圧潰試験や, 八ニカムセルの全面に衝撃 負荷を加える圧縮試験, あるいは有限要素解析を実施 して, ハニカムセル構造材の衝撃エネルギ一吸収特性 を評価する研究(9) (13) が行われつつある. また, 熱可 塑性樹脂の不織布で製作されたペーパハニカムコアに 関しても, 準静的および動的な条件において, 衝撃工 ネルギー吸収特性を解明する研究が行われてい る(14). ところがこれらの研究のほとんどは, 八ニカム セル構造材の各種パラメータ (セルサイズ, はく厚等) 
の組合せと, 衝撃エネルギー吸収特性, 圧潰変形挙動 の関係を調べるものである.

八ニカムセル構造材が緩衝材や相包材としても利用 されている現在, 保護すべき内容物損傷の原因となる 初期圧潰荷重を低減し, かつ高い衝撃エネルギー吸収 性能を有するハニカムセル構造材を開発することは, 社会的要求から見ても非常に重要である.これまで, 高い衝撃エネルギー吸収性能が要求される使用条件下 においては, セルサイズの小寸法化, あるいはセルは く厚の厚いハニカムセル構造材を用いるのが一般的で あった．しかし，こうした方法を採用すると体積や重 量だけではなく, 初期圧潰荷重も増加するという問題 が生じる.そこで, 以上のような問題の対策として, ピラミッド形八ニカムセル構造材も提案されてい る(5).これは, 従来の多段積層八二カムパネルの形状 を, 最上段より順次拡大したピラミッド形にすること で, 体積当たり.の衝撃エネルギー吸収量の増加を実現 している.ところが，ピラミッド形八ニカムセルは, 各上下段の受圧面積が異なるために局部的な圧潰が生 じやすく，これが抵抗となって圧潰荷重が増加すると いう問題が指摘されている.

したがって, ハニ゙カムセル構造材の初期圧潰荷重を 低減し, かつ高い衝撃エネルギー吸収性能を有する八 ニカムセル構造材を開発するための対策は, 十分に確 立されていない. よって, 従来の研究における主要な 課題は, 以下のようにまとめられる.

（1）重量当たり，および容積当たりの衝撃エネル ギー吸収量が飛躍的に増大するハニカムセル構造材の 提案.

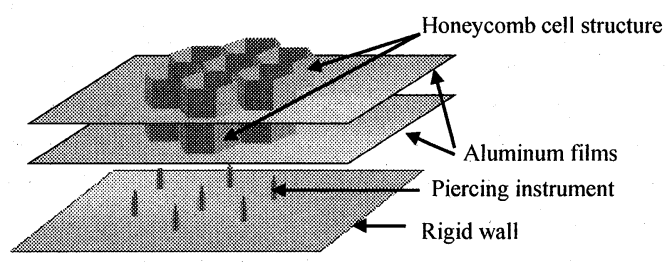

(a) Bird's eye view

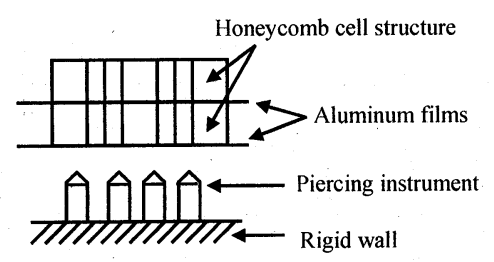

(b) Side view

Fig. 1 Honeycomb cell structure with thin film
（2）初期圧潰荷重を低減する新たな方法の考案. そこで本論文では，上記（1），（2）の対策として, 薄板や立体セルに積極的かつ連続的に塑性圧潰と薄板 の破壊を誘発する. 膜付き八ニカムセル構造材を提案 する. 図1(a), (b)に示すように, 高さ一定のアル ミ八ニカムセル底面に, アルミニウム薄板を接着した ものを数段重ねることで, セルの連続的な塑性圧潰と 薄板の破壊を交互に発生させ, 重量当たり, および容 積当たりの衝撃エネルギー吸収量の増加を図る，その 薄板の破壊を誘発させるため, 剛体壁側にハニカムセ ルのピッチに合わせて配置した, 先端の尖ったピン状 の貫通体を設ける.この理由は, セル自体の初期圧潰 が生じる前に, ハニカムセル下端面に接着した薄板を ピン状貫通体で破壊させ，初期圧潰荷重の低減を図る ためである.図 1(a ) は立体的なハニカムセル構造材 と貫通体を, 図 1(b) はその側面図を示している.

始めに, 提案モデルについて動的有限要素解析を行 つて, 膜付きハニカムセル構造材の各種パラメータと 衝撃エネルギー吸収量, 圧潰荷重の関係, および衝撃 圧潰現象を明らかにした結果を示す。そして, 衝撃圧 潰試験により, 膜付きハニカムセル構造材の衝撃エネ ルギー吸収量を実験的に求める。試験により得られた 結果を動的有限要素解析結果と比較して, 膜付きハニ カムセル構造材の有効性を確認し, 最後に結論を述べ る.

\section{2. 動的有限要素解 析}

これまでに著者らは,アルミハニカムセル構造材の 衝撃エネルギー吸収性能, およびアルミニウム薄板の 衝撃エネルギー吸収特性に関する検討(15)(16)を行って きた，本章では，これまでの研究で得られた知見を基 に, まず動的有限要素解析を実施し, 膜付きハニカム セル構造材の衝撃エネルギー吸収性能, 圧潰荷重の変 動および圧潰挙動を明らかにする. 解析には動的有限 要素解析ソフトウェア LS-DYNA を使用した。

$2 \cdot 1$ 膜付きハニカムセル構造材のモデル化 本 論文では, 八ニカムセル構造材の六角形セルの規則的 な対称構造・変形を利用した簡易モデルを解析対象と した.

文献 $(9)$ によると, セル壁どうしの接着接合を考慮 しない場合は, ハニカムセル形状・変形の周期性から 得られる最小モデルは, 図 2(a)に示す六角形セルを 12 等分した $1 / 12$ モデルとなる. 図 2 において, 接着 部分は $\mathrm{OA}$ のであり, セルはく厚を $T$ とすると OB および $\mathrm{OC}$ は $T$ であり, OA $2 T$ となる. $1 / 12$ モデルは接着面が比較的容易にはく離して, 2 枚のセ 
ルが独立して圧潰することを前提にしている．しか し, 著者らが行ったアルミハニカムセル構造材の衝撃

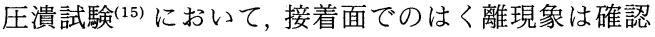
されなかった。そこで本論文では, 図2(b)に示す $1 / 6$ モデルを採用した。 なお, 図 2 中の斜線部は占有 面積 $A$ を表しており, 解析モデルの対象となる部分 である. 占有面積 $A$ とセルサイズ $S$ との関係も, 合 わせて図 2 中に示しておく、四 2 からわかるように, $1 / 12$ モデルでは $\mathrm{OA}$ 部のはく厚が $T$ となるのに対 し, $1 / 6$ モデルでは $2 T$ となる.

$2 \cdot 2$ 解析モデル セルサイズ $S=19.05 \mathrm{~mm}$, セ ルはく厚 $T=0.076 \mathrm{~mm}$, ハニカムセル構造体全体の 高さ $H=40.00 \mathrm{~mm}$ に固定して, アルミニウム薄板の 板厚 $t$ 抢よ゙゙枚数(段数)を, 表 1 のように変化させた

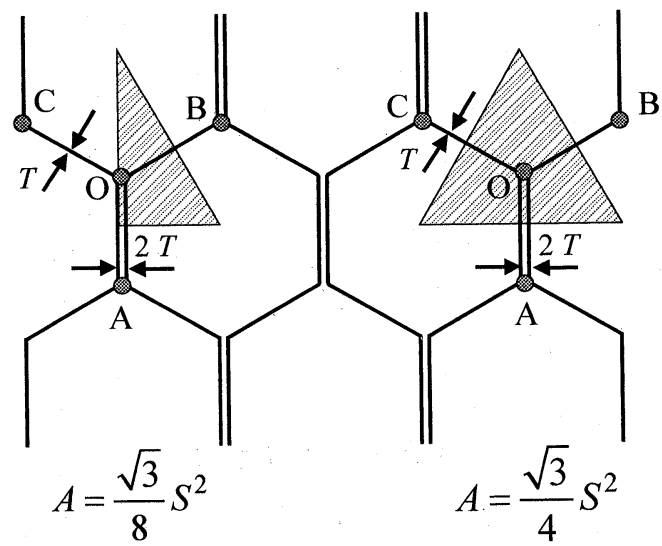

(a) 1/12 model

(b) $1 / 6$ model

Fig. 2 Unit cell area

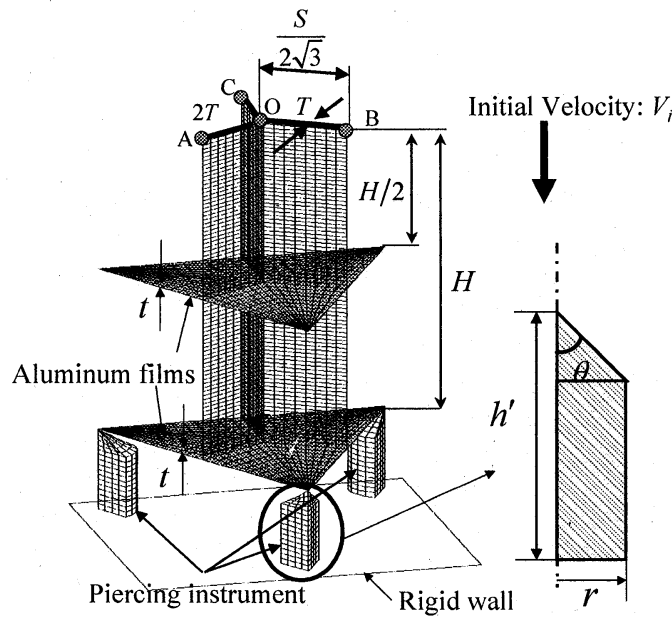

Fig. 3 Simulation model with film (Type B model)
8 種類の解析モデルを対象とした，膜破壊をさせる薄 板を 4 枚有するモデルを Type A，2 枚有するモデル を Type B と呼称し, その後にアルミニウム薄板の板 厚 $t$ (単位: $\mathrm{mm}$ ) を付記して各モデルを表す。一例と して Type B の解析モデルを図 3 に示す。OA 部はは く厚が $2 T$ であり, $\mathrm{OB}$ および $\mathrm{OC}$ 部ははく厚 $T$ であ る.

また, 衝撃エネルギー吸収性能の比較を行うために, 貫通体を取り去った膜破壊を誘発させないモデルの解. 析も実施した。このモデルに関しては，添字 0 を付記 して各モデルを表す。

アルミハニカムセルおよびアルミニウム薄板の離散 化には，四辺形一次シェル要素および三角形一次シェ ル要素を, 貫通体にはソリッド要素を用いた。 Type A モデルは総節点数 6378 , 総要素数 4788 で, Type B モデルは総節点数 4722 , 総要素数 3732 で離散化し た.アルミニウム材料は弾塑性体として扱い, ミーゼ スの降伏条件と双一次形の応力ーひずみ関係を仮定し た。アルミハニカムに用いられる $\mathrm{Al} 3000$ 系材を仮定 し, 解析に用いた材料定数を表 2 に示す。また, 図 3 右に示す貫通体 (半径 $r=2.5 \mathrm{~mm}$, 高さ $h^{\prime}=10 \mathrm{~mm}$, 先端角度 $\left.2 \theta=90^{\circ}\right)$ の材料は軟鋼想定し, 密度 $\rho=$ $7.87 \times 10^{3} \mathrm{~kg} / \mathrm{m}^{3}$, 繸弾性係数 $E=2.06 \times 10^{2} \mathrm{GPa}$, ポ アソン比 $\nu=0.31$ とした.

解析では, ハニカムセルは剛体壁と接触した後, 連 続的な塑性圧潰を生じることから, 剛体壁との接触お

Table 1 Dimension of models

\begin{tabular}{c|c|c}
\hline \hline Specimen Type & Film thickness $\mathrm{t}[\mathrm{mm}]$ & $\begin{array}{c}\text { Number of } \\
\text { penetrated films }\end{array}$ \\
\hline Type A-0.1 & 0.1 & 4 \\
\hline Type $\mathrm{B}-0.1$ & 0.1 & 2 \\
\hline Type A-0.2 & 0.2 & 4 \\
\hline Type $\mathrm{B}-0.2$ & 0.2 & 2 \\
\hline Type $\mathrm{A}_{0}-0.1$ & 0.1 & - \\
\hline Type $\mathrm{B}_{0}-0.1$ & 0.1 & - \\
\hline Type $\mathrm{A}_{0}-0.2$ & 0.2 & - \\
\hline Type $\mathrm{B}_{0}-0.2$ & 0.2 & - \\
\hline
\end{tabular}

Table 2 Mechanical properties of honeycomb cell

\begin{tabular}{c|c}
\hline \hline Density $: \rho\left[\mathrm{kg} / \mathrm{m}^{3}\right]$ & $2.71 \times 10^{3}$ \\
\hline Young's modulus : $E[\mathrm{MPa}]$ & $6.9 \times 10^{4}$ \\
\hline Poisson's ratio $: v$ & 0.33 \\
\hline Yield stress $: \sigma_{y}[\mathrm{MPa}]$ & $1.86 \times 10^{2}$ \\
\hline Hardening modulus $: E_{T}[\mathrm{MPa}]$ & $3.94 \times 10$ \\
\hline Cell thickness : $T[\mathrm{~m}]$ & $7.60 \times 10^{-5}$ \\
\hline
\end{tabular}


よび圧潰後のセル壁どうしの接触を考慮した.またア ルミニウム薄板と貫通体の接触には, 動摩擦係数 $\mu=$ 0.3 を与えて, 摩擦を伴う接触変形を考慮した. 衝突 速度は, 板厚 $t=0.1 \mathrm{~mm}$ のアルミニウム薄板を有す るモデルに対して $V_{i}=6.6 \mathrm{~m} / \mathrm{s}$, 板厚 $t=0.2 \mathrm{~mm}$ の アルミニウム薄板を有するモデルに対して,$V_{i}=10.0$ $\mathrm{m} / \mathrm{s}$ を与えた。 また, 図 3 に示すモデルの上端面 OA, $\mathrm{OB}, \mathrm{OC}$ の各節点に, 付加質量(後述する衝撃圧潰試 験において, 試験片に衝突させる衝撃子の質量を $1 / 6$ 解析モデル当たりに換算)を一様に付加した. 対称面 の節点に対しては, 対称性を考慮した境界条件を与え た.アルミニウム薄板に発生するき裂の進展挙動解析 には, 図 4 に示すようなグループ化した節点における 相当塑性ひずみ值が, 限界值 $\varepsilon_{p}=0.15$ に達すると節 点間の拘束を切り離す方法を採用し, 限界值には破断 ひずみ值(17)を用いた. 図 4 ( a )の口印は薄板部分の グループ化した節点を表し, このグループ化した節点

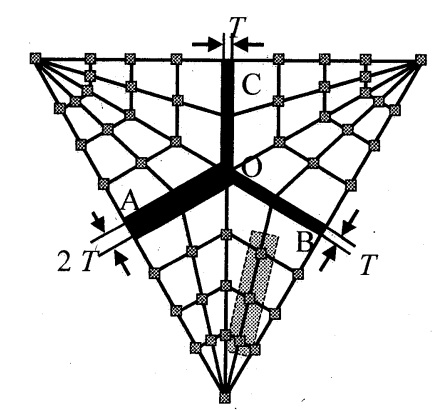

(a) Simulation model of aluminum

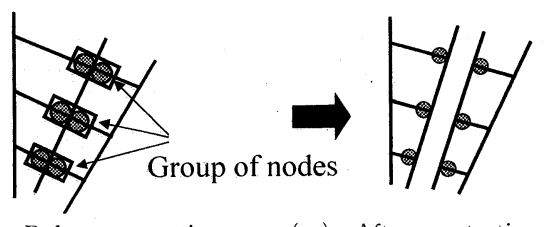

(b) Before penetration

(c) After penetration

Fig. 4 Simulation model of penetration

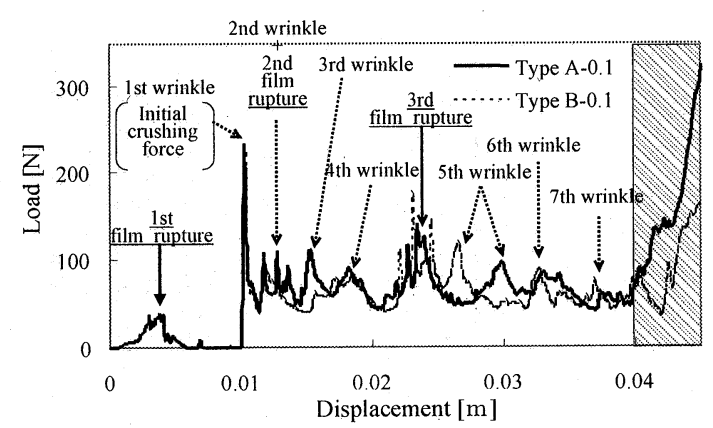

Fig. 5 Load-displacement curves (film thickness 0.1 $\mathrm{mm}$ )
で破断が起きうる．太線部分はハニカムセル壁を表し ている。また図 4(a) 中の破線で囲まれた灰色部の詳 細を図 4(b)に示す.すなわち, 図 4(a) の四印の中 には図 4(b) に示すとおり二つの節点が拘束されてお り，破断ひずみ值に到達したときに，図 4( c ) のよう に節点が離れるようにした。またき裂の進展方向は, 著者らが以前に行ったアルミニウム薄板の貫通実験結 果(16)より予測した。各モデルの衝撃エネルギー吸収 量は, 荷重-変位線の面積より算出し, 荷重は剛体壁か らの反力を用いた。

$2 \cdot 2 \cdot 1$ 板厚 $t=0.1 \mathrm{~mm}$ モデル 解析結果の代 表例として, 図 5 に Type A-0.1 モデルの荷重-変位 曲線を実線で, Type B-0.1 モデルの荷重-変位曲線を 破線で示す。

また，単位体積当たりの衝撃エネルギー吸収量およ び初期圧潰荷重に関し, Type $\mathrm{A}_{0}-0.1$ モデルおよび Type $\mathrm{B}_{0}-0.1$ モデルとの比較結果を表 3 に示す.

まず，最下端面に設けたアルミニウム薄板に破壊が 生じ [図6(a)]，小さな荷重ピークを生じる．その 後, 荷重は八ニカムセルの変形が進行するにつれて上 下動を繰返し, 最下段のハニカムセルに最初のしわが 形成される過程で, 初期圧潰荷重と呼ばれる大きなピ ークを生じる.そして, セルの連続的な塑性圧潰によ ってしわの形成が起こるごとにピークを生じ, 薄板の 破壊を誘発するとやや大きなピークを生じる. Type

Table 3 Simulation results (film thickness $0.1 \mathrm{~mm}$ )

\begin{tabular}{l|c|c|c|c}
\hline \hline SpecimenType & Type A-0.1 & Type $\mathrm{A}_{0^{-}}-0.1$ & Type $\mathrm{B}-0.1$ & Type $\mathrm{B}_{0^{-}-0.1}$ \\
\hline $\begin{array}{l}\text { Specific energy } \\
\text { absorption }\left[\mathrm{MJ} / \mathrm{m}^{3}\right]\end{array}$ & 16.57 & 14.18 & 18.31 & 17.29 \\
\hline $\begin{array}{l}\text { Initial crushing force } \\
{[\mathrm{N}]}\end{array}$ & 185 & 225 & 182 & 228 \\
\hline
\end{tabular}

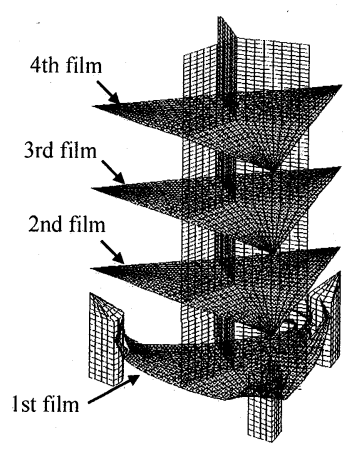

(a) Rupture of 1 st film

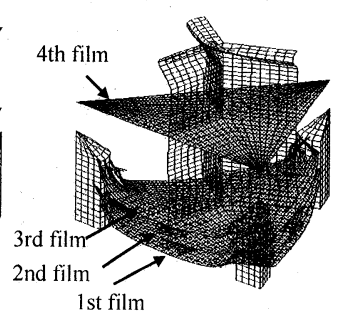

(b) Rupture of 4 th film
Fig. 6 Deformed shape of Type A-0.1 model 
A-0.1 モデルでは, 3 枚めのアルミニウム薄板が貫通 した後, ハニカムセルの上端面からも圧潰を生じ始め た [図 6(b)].一方で Type B-0.1 モデルは, 2 枚め のアルミニウム薄板が貫通した後, 八ニカムセル上端 面から圧潰が進行するパターンであった。また図 5 の 斜線部で示した領域では, 荷重が急激に上昇してい る.これは, 八ニカムセルが完全に圧潰した後も解析 を継続して，さらに変形を進行させようとするために 生じたものである.したがって, 本論文では変位が $0.04 \mathrm{~m}$ を超えた領域を完全圧潰後であるとして無視 し, 各モデルの衝撃エネルギー吸収量を算出した.

表 3 において, Type A-0.1 モデルおよび Type B0.1 モデルの単位体積当たりの衝撃エネルギー吸収量 を, Type $\mathrm{A}_{0}-0.1$ モデルおよび Type $\mathrm{B}_{0}-0.1$ モデル と比較すると, Type A-0.1 モデルでは 17\%, Type B-0.1 モデルでは 6\%増加する結果となり, 衝撃エネ ルギー吸収性能の向上が確認された。 またハニカムセ ルの最下端面に薄板を設けることによって, セルの初 期圧潰は薄板の破壊後に生じる圧潰パターンとなるこ とから, 初期圧潰荷重は膜破壊を誘発させないモデル と比較して，20\%程度低減されていることが表 3 より わかる.

$\mathbf{2 \cdot 2 \cdot 2}$ 板厚 $t=0.2 \mathrm{~mm}$ モデル 解析結果の代 表例として, 図 7 に Type A-0.2 モデルの荷重-変位 曲線を実線で, Type B-0.2 モデルの荷重-変位曲線を 破線で示す。また, 単位体積当たりの衝撃エネルギー 吸収量および初期圧潰荷重を, Type $\mathrm{A}_{0}-0.2$ モデルお

Table 4 Simulation results (film thickness $0.2 \mathrm{~mm}$ )

\begin{tabular}{l|c|c|c|c}
\hline \hline SpecimenType & Type A-0.1 & Type $\mathrm{A}_{0}-0.1$ & Type B-0.1 & Type $\mathrm{B}_{0}-0.1$ \\
\hline $\begin{array}{l}\text { Specific energy } \\
\text { absorption }\left[\mathrm{MJ} / \mathrm{m}^{3}\right]\end{array}$ & 12.15 & 7.69 & 14.72 & 8.96 \\
\hline $\begin{array}{l}\text { Initial crushing force } \\
{[\mathrm{N}]}\end{array}$ & 198 & 251 & 196 & 259 \\
\hline
\end{tabular}

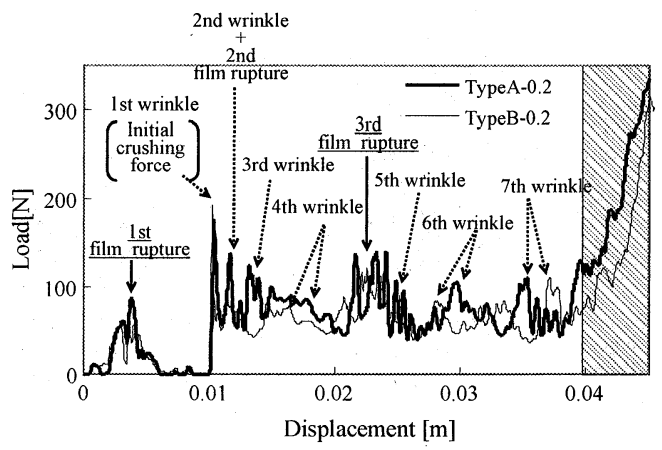

Fig. 7 Load-displacement curves (film thickness 0.2 $\mathrm{mm}$ )
よび Type $\mathrm{B}_{0}-0.2$ モデルと比較して表 4 に示す.

アルミニウム薄板の板厚 $t$ を増加したことで, 薄板 の破壊により生じるピーク荷重は, 板厚 $t=0.1 \mathrm{~mm}$ のモデルと比較してやや大きくなる.また, 最初のし わが形成される過程で大きなピークである初期圧潰荷 重を生じ, その後荷重は上下動を繰返して, セルの連 続的な塑性圧潰と薄板の破壊を誘発する. 板厚 $t=$ $0.2 \mathrm{~mm}$ モデルでは 2 枚めのアルミニウム薄板に破壊 が生じ始めると, 上端面からもセルが圧潰を始めた [図 8(b)]. その後, セルの連続的な塑性圧潰が主に 上面から進行すると同時に, Type A-0.2 モデルでは, 3 枚め以降のアルミニウム薄板の破壊を誘発する圧潰 パターンとなった.

表 4 において, 各モデルの単位体積当たりの衝撃エ ネルギー吸収量を, Type $\mathrm{A}_{0}-0.2$ モデルおよび Type $\mathrm{B}_{0}-0.2$ モデルと比較すると, Type A-0.2 モデルでは 約 58\%, Type B-0.2 モデルでは約 64\%増加してお り，衝撃エネルギー吸収性能の大幅な向上が確認され た。また初期圧潰荷重は, 膜破壊を誘発させないモデ ルと比較して $20 \%$ 程度低隇されており, アルミニウム 薄板の板厚 $t$ を増すことによって, 衝撃エネルギー吸 収量を大幅に増加できたことが表 4 よりわかる.

\section{3. 衝 撃 圧 潰 試 験}

2 章において, アルミニウム薄板の板厚 $t$ および枚 数が, 膜付きハニカムセル構造材の衝撃エネルギ一吸 収量, 初期圧潰荷重および圧潰挙動に及ぼす影響につ いて, 解析的に評価した. その結果, 膜付きハニカム セル構造材は, 八ニカムセルによる連続的な塑性圧潰 と薄板の破壊を誘発することで, 初期圧潰荷重を低減 でき, 単位体積当たりの衝撃エネルギー吸収性能を大 幅に向上することが期待できる. (a) Rupture of 1 st film

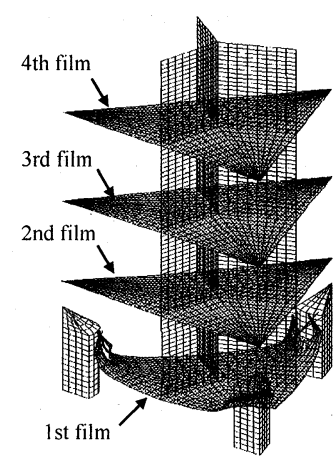

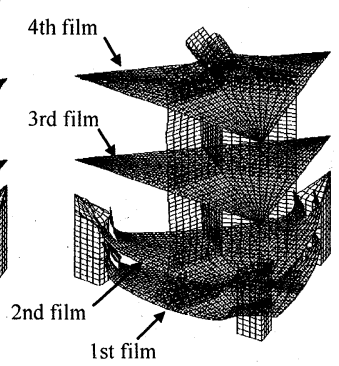

(b) Rupture of 3 rd film
Fig. 8 Deformed shape of Type A-0.2 model 
そこで,アルミニウム薄板の板厚 $t=0.1 \mathrm{~mm}$ の デルに対して衝撃圧潰試験を実施して, 衝撃エネルギ 一吸収量を実験的に求め, 圧潰挙動の観察を行った。

$3 \cdot 1$ 試験方法 今回用いた試験装置の概略を図 9 (a)に, また図 9 (a)の点線で囲った八ニカムセル構 造体が圧潰する部分の拡大写真を図 $9(\mathrm{~b})$ に，それぞ れ示す.

円柱形衝撃子 (軟鋼製, 質量 $7.0 \mathrm{~kg}$, 直径 $50 \mathrm{~mm}$ ) が ハニカムセル軸方向に対して水平に衝突する形式を採 用して, 装置の動力源に管状ゴム (外径 $40 \mathrm{~mm}$, 内径 $30 \mathrm{~mm}$ )を用いた。衝撃子を載せた台車に管状ゴムを 取付けて, ウィンチで引張り十分な復元力を得る。 そ

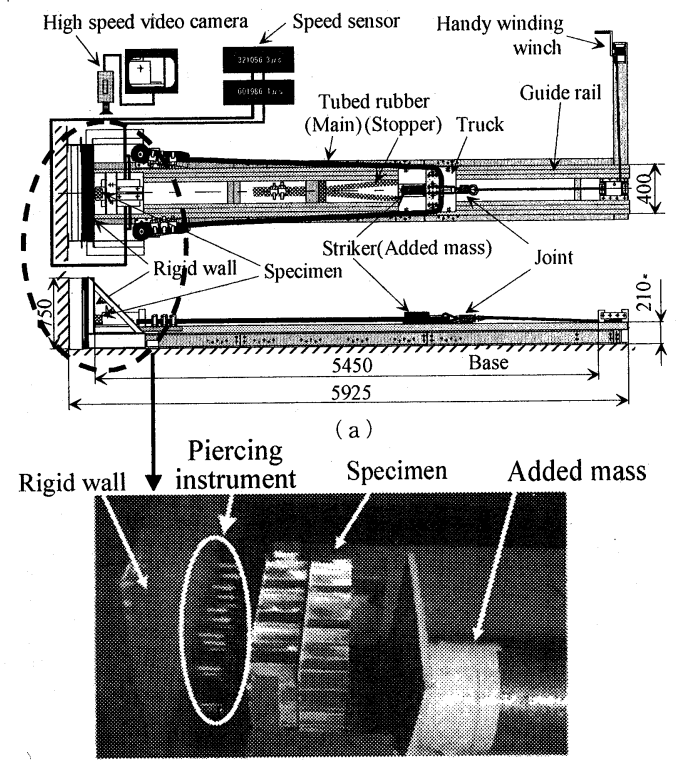

(b)

Fig. 9 Experimental setup (unit: $\mathrm{mm}$ )

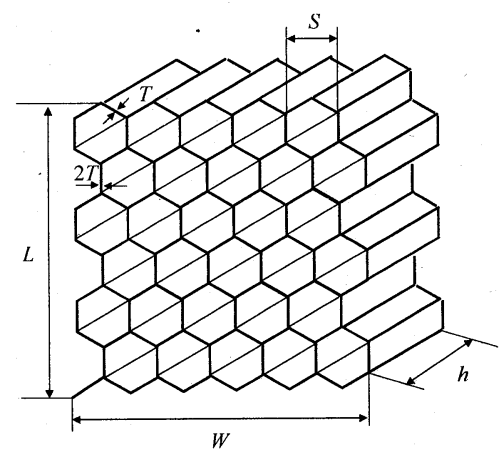

Fig. 10 Crush test specimen of honeycomb cell structure with thin film
して, ウィンチと台車の連結ピンを瞬時に解除するこ とにより, 台車がレール上を加速していく．その後, 停止用の管状ゴムによって台車が減速すると, 衝撃子 のみが飛び出して試験片に衝突する仕組みである. 衝 撃子の初速度 $V_{i}$ は, 動的有限要素解析と同様の条件 で与えた。

文献(18)では, 薄肉管の衝撃エネルギー吸収特性を

Table 5 Results of crush test (film thickness $0.1 \mathrm{~mm}$ )

\begin{tabular}{l|c|c|c|c|c}
\hline \hline $\begin{array}{l}\text { Specimen Type } \\
\begin{array}{l}\text { Total energy } \\
\text { absorption [J] }\end{array}\end{array}$ & Type A & ${\text { Type } \mathrm{A}_{0}}$ & Type B & Type $\mathrm{B}_{0}$ \\
\hline $\begin{array}{l}\text { Specific energy } \\
\begin{array}{l}\text { absorption } \\
{\left[\mathrm{MJ} / \mathrm{m}^{3}\right]}\end{array}\end{array}$ & $\mathrm{E}$ & 17.14 & 15.98 & 21.31 & 19.9 \\
\cline { 2 - 6 } & $\mathrm{A}$ & 16.57 & 14.18 & 18.31 & 17.29 \\
\hline E/A & 1.03 & 1.13 & 1.16 & 1.15 \\
\hline Number of wrinkle & $6 \sim 7$ & $6 \sim 7$ & $6 \sim 7$ & $6 \sim 7$ \\
\hline Penetrated film & $3 \sim 4$ & - & $1 \sim 2$ & - \\
\hline
\end{tabular}

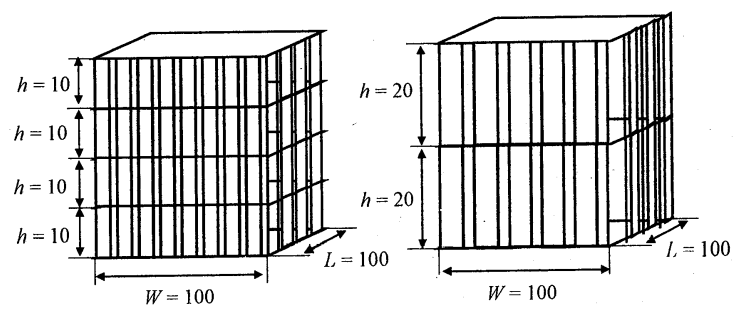

(a)

(b)

Fig. 11 Experimental models

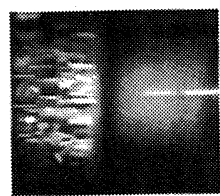

$1 \mathrm{msec}$

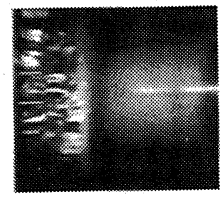

$3 \mathrm{msec}$

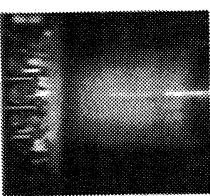

$5 \mathrm{msec}$

(a) Type A-0.1 model

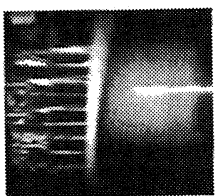

$1 \mathrm{msec}$

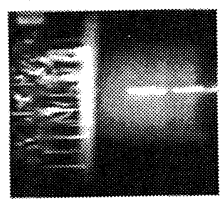

$3 \mathrm{msec}$

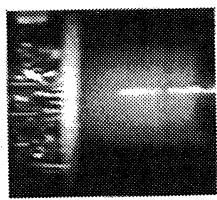

$5 \mathrm{msec}$

(b) Type B-0.1 model
Fig. 12 Crushing behavior of specimen 
求める際に, 運動エネルギーの差から衝撃エネルギー 量を算出する手法を用いているので, 本試験において もこの手法を採用した. まず, 透過形光速度センサ $(0.1 \mu \mathrm{s}$ まで計測可能)により,一定区間の衝撃子の通 過時間を測定し, 衝突前後の速度 $V_{i}$ および $V_{r}$ を求 める。そして, 次式から試験片の座屈圧潰による衝撃 エネルギー吸収量 $E$ を算出した。

$$
E=\frac{1}{2} m V_{i}^{2}-\frac{1}{2} m V_{r}^{2}
$$

また,アルミニウム薄板の枚数の違いによる変形挙 動の相違を観察するために, 高速度ビデオカメラ $(1.0$ $\mathrm{ms} / コ マ) に よ っ て$, 衝突前後の圧潰過程の撮影を行 つた.

$3 \cdot 2$ 試験片 用いた試験片は, 解析モデルと同 様のセルサイズ $S$, セル厚 $T$ および材料定数を持つ アルミハニカムである. 本試験では, 図 10 に示すよ うな $W \times L=100 \mathrm{~mm} \times 100 \mathrm{~mm}, 1$ 段のセル高さ $h=$ $10 \mathrm{~mm}, 20 \mathrm{~mm}$ の 2 種類の試験片を用意した.

各八ニカムセルの一端には, 八ニカムセルと同様の 機械特性を持つ厚さ $t=0.1 \mathrm{~mm}$ のアルミニウム薄板 が接着されており, セル高さ $h=10 \mathrm{~mm}$ のもは 4 段, $20 \mathrm{~mm}$ のものは 2 段重ねることで, 全体の高さ $H$ を $40 \mathrm{~mm}$ とし, 試験片 Type A-0.1および Type B-0.1を作製した. Type A-0.1を図11(a)に, Type B-0.1 を図 11(b)にそれぞれ示す。またアルミ ニウム薄板に破壊を促す貫通体を剛体壁面上に, 各八 ニカムセルの中央へ位置するよう設置した。

$3 \cdot 3$ 衝撃圧潰試験結果試験結果より算出され た全衝撃エネルギー吸収量, 単位体積当たりの衝撃エ ネルギー吸収量, 形成されたしわ数, および貫通した アルミニウム薄板数について, 解析と比較して表 5 に 示す. 各実験値は, 4 回の試験を行って得られた値の 平均値を示している. 表中の $\mathrm{E}$ は実験により得られ た值，Aは解析により得られた值を意味する。また, Type A-0.1 モデルおよび Type B-0.1 モデルの圧潰 挙動の一例を, 図 12 ( a )および (b)にそれぞれ示す.

まず衝撃子が試験片に衝突することで, 最下端面の アルミニウム薄板に初期き裂が生じる. 時間の経過と ともにき裂は進展し，3〜4 本のき裂を形成して貫通に 至る (図 13).

その直後, ハニカムセルの下端面に初期圧潰が生じ て, セル壁が連続かう一定の折れ幅でアコーディオン 状に内外に折れ曲がる. Type B-0.1 モデルでは, 2 枚めのアルミニウム薄板の破壊を誘発した後に, ハニ カムセルの上端面からも圧潰を起こして完全圧潰に至 る. 一方, Type A-0.1 モデルでは 3 枚めの薄板が貫

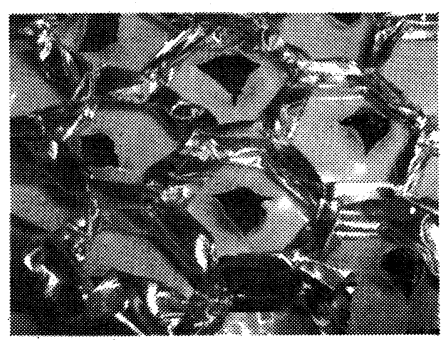

Fig. 13 Penetrated aluminum film

通に至ると, セルの塑性圧潰が上端面からも生じ始め た.これらは, 動的有限要素解析において確認した圧 潰パターンと同様である。

全衝撃エネルギー吸収量は，アルミニウム薄板の枚 数が多いほど増加する傾向にある。単位体積当たりの 衝撃エネルギー吸収量を, Type $\mathrm{A}_{0}-0.1$ モデルおよび Type $\mathrm{B}_{0}-0.1$ モデルと比較すると, Type A-0.1 モデ ルでは約 7\%, Type B-0.1 モデルでは約 7\%増加して おり, 衝撃エネルギー吸収性能の向上が確認された。 セル壁に形成されたしわ数は，いずれの試験片におい ても解析結果とほぼ一致していることを確認した。

\section{4. 結論}

本論文では, 初期圧潰荷重を低減し，かつ従来より も衝撃エネルギー吸収性能の優れたハニカムセル構造 材の開発を目指して, 膜付きハニカム構造材を設計・ 試作した。

まず, 8 種類の解析モデルについて, 動的有限要素 解析による衝撃エネルギー吸収シミュレーションを行 い, アルミニウム薄板の板厚 $t$ や枚数が衝撃エネルギ, 一吸収量, 初期圧潰荷重や圧潰挙動に与える影響を検 討した. 合わせて衝撃圧潰試験を行って, 各試験片の 衝撃エネルギー吸収量を実験的に求め, 圧潰挙動の観 察を行って膜付きハニカム構造材の有効性を検討し た. 得られた主な結果は, 以下に示すとおりである.

（1）従来のハニカムセル構造材と比較して, 膜付 きハニカムセル構造材は, より高い衝撃エネルギー吸 収効果がある。

（2）薄膜の破壊を誘発する膜付きハニカムセル構 造材は初期圧潰荷重の低減が可能である.

今後は, 単位体積当たりの衝撃エネルギー吸収性能 がさらに向上する, 膜付きハニカムセル構造材の開発 を目指して, 貫通体の先端角度 $\theta$ や形状, アルミニウ 厶薄板の板厚 $t$ や枚数等のパラメータの範囲を広げた 検討が必要である。 


\section{文}

\section{献}

(1) Bitzer, T., Honcycomb Technology, (1997), p. 98, CHAPMAN \& HALL

(2) Utida, M., Design and Process of Advanced Compositc (in Japanese), (1998), p. 105, Kogyo Tyosa Kai.

(3) Gibson, L. J. and Ashby, M. F., Cellular solids, (1993), p. 1. 97. Uchidaroukakuho.

(4) Kobayashi, H. et al., Elasto-Plastic Bending Deformation of Welded Honeycomb Sandwich Panel, Transac tions of the Japan Socicty of Mechanical Enginecrs, Scrics A, Vol. 60, No. 572, pp. 103-108.

(5) Yasui, Y. et al., Buffer Characteristics of Multistage Honeycomb Panels Subjected to Impact Loads, Transactions of the Japan Socicty of Mechanical Engineers, Series A, Vol.61, No. 589 (1995), pp. 117-123.

(6) Fujiwara, A. and Hashimura, T., Design Considera. tions Conceming Axial Collapse Characteristics of Circular Tubes, Transaction of the Japan Socicty of Mcchanical Enginecrs, Series A, Vol.64, No.620 (1998), pp. 231-238.

( 7) Yamazaki, K. et al., A Study on Maximization of Dynamic Crushing Energy Absorption of Cylindrical Shell Structures, Transactions of the Japan Society of Mechanical Engineers, Serics A. Vol.64, No. 620 (1998), pp. 239-245.

(8) Yoshii, A. and Chikugo, R., Peel Stress as Face-tocore Interface in Sandwich Plate, Procecdings of Conference on Matcrials and Mechanics, No. 910-71 (1991-11), pp. 18-20.

(9) Ogasawara, N. et al., Energy Absorption by Honeycomb Structure (1 st Report. Progressive Buckling under Quasi-Static Condition), Transactions of the Japan Socicty of Mcchanical Enginecrs, Serics A, Vol. 63, No. 608 (1997), pp. 118-123.

(10) Ogasawara, N. et al., Energy Absorption by Honey- comb Structure (2 nd Report, Evaluation of Collapsing Stress under Impact Condition), Transactions of the Japan Socicty of Mechanical Engineers, Series A, Vol. 63, No. 616 (1997), pp. 111-115.

(11) Watanabe, M. et al., Study on the Impact Property of the Honeycomb Sandwich Panel, Transactions of the Japan Socicty of Mechanical Engineers, Series A, Vol. 69, No. 678 (2003), pp. 33-40.

(12) Kawano, S. et al., Buckling Strength of Honeycomb Core of Aluminum Alloy, Transactions of the Japan Socicty of Mechanical Engineers, Series A, Vol. 64, No. 627 (1998), pp. 145-150.

(13) Santosa, S. and Wierzbicki, T., Crash behavior of box columns filled with aluminum honeycomb or foam, Computers and Structures, Vol. 68, No. 4 (1998), p. 347.

(14) Kobayashi, H. et al., Dynamic and Static Compression Tests for Paper Honeycomb Core and Absorbed Energy, Transactions of the Japan Society of Mechanical Engineers, Series A, Vol.63, No.616 (1997), pp. 116-121.

(15) Kitayama, S. et al., A Study on the Crush Worthiness of Honeycomb Structure, Proceedings of the 2003 Annual Mecting of the JSME/MMD, No. 03-11 (20039), pp. 1079-1080.

(16) Furutochi, M. et al., A Study of Absorption Characteristics Penetration Energy for Ductile Material, Pro. ceedings of the 2003 Annual Conference of the Japan Socicty of Mechanical Engineering (Mechanical Engineering Congress), No. 03-1, (2003), pp. 7-8.

(17) The Japan Institute of Metals, Date Book of Metals, (1974), p. 162, Maruzen Co., Ltd.

(18) Sogo, T. et al., Analysis of Energy Absorption Abilities of Thin-Walled Tubes by Impact Axial Crushing, Transactions of the Japan Society of Mechanical Enginecrs, Series A, Vol. 63, No. 605 (1997), pp. 146-151. 